УДК 666.29.051.3, 621.793, 539.23

Іванченко С.Е., Умерова С.О., Дуліна I.О., Барановський Д.І., Рагуля А.В.

Інститут проблем матеріалознавства НАН України ім. І.Н. Францевича, м. Київ

\title{
РЕОЛОГІЧНІ ВЛАСТИВОСТІ ТА ПЛІВКОУТВОРЮЮЧА ЗДАТНІСТЬ ПОЛІМЕРНИХ СУСПЕНЗІІ̆ НА ОСНОВІ НАНОПОРОШКУ ВаТіОЗ
}

У роботі досліджувався вплив зміни типу основних компонентів суспензій $i$ їх кількості на властивості суспензій для плівкового лиття та отриманих із них плівок. Встановлені залежності, щзо дозволяють підібрати склад суспензї для лиття тонких діелектричних плівок і використання їх в багатошарових керамічних конденсаторах.

В работе исследовалось влияние изменения типа основных компонентов суспензий и их количества на свойства суспензий для пленочного литья и полученных из них пленок. Установлень зависимости, позволяющие подобрать состав суспензии для литья тонких диэлектрических пленок и использования их в многослойных керамических конденсаторах.

In this work, the effect of changing the type of the main components and their quantities on the properties of suspensions for Tape Casting where investigated. The dependencies that allow choosing the composition of slurry for casting thin dielectric films for use in multilayer ceramic capacitors were established.

\section{Вступ}

Полімерні суспензії на основі нанорозмірних частинок функціональних матеріалів представляють собою перспективний клас новітніх матеріалів для створення плівок різними методами колоїдного формування. У контексті стрімкого розвитку галузі друкованої електроніки особливий інтерес представляє технологія плівкового лиття, яка дозволяє отримувати тонкі еластичні плівки з високою щільністю, наперед заданою товщиною та рівномірним розподілом порошку в об'ємі. Використовуючи нескладне обладнання, технологія дозволяє отримати плівки з будь-якого матеріалу, який можна отримати у вигляді порошку. Технологія також $\epsilon$ високопродуктивною і екологічною. Метод широко використовується у виробництві, постійно модернізується і є основою для виготовлення усієї сучасної електроніки.

Технологія плівкового лиття передбачає отримання суцільних планарних керамічних плівок із товщиною від 3 мкм [1] до 3 мм [2] шляхом лиття суспензій на 
машинах різної конструкції за допомогою стаціонарної або рухомої філь'єри 3 резервуаром для суспензії, яка встановлюється на носій, і лезом (доктор Блейд) (рис. 1).

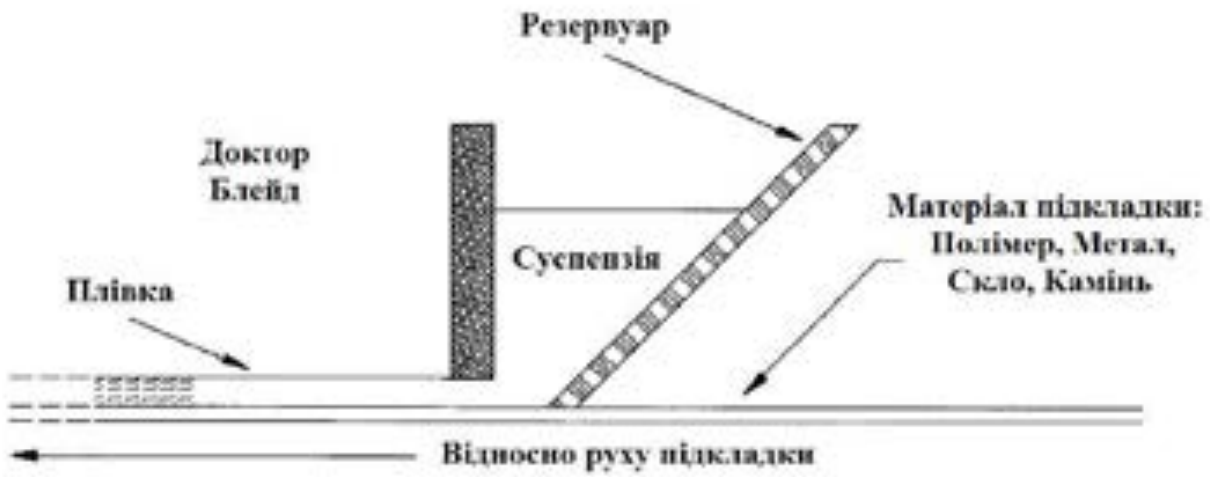

Рис. 1. Схема філь'єри для плівкового лиття

Суспензія для плівкового лиття складається з наступних основних компонентів: тверда фаза у вигляді порошку, що буде визначати область застосування плівки, полімерв’яжуче, що буде формувати полімерну сітку, пластифікатор, що, взаємодіючи 3 полімерними ланцюгами, надасть плівці необхідної гнучкості та еластичності, i розчинник, що застосовувався для приготування розчинів полімеру та пластифікатору. Властивості плівок $\mathrm{BaTiO}_{3}$ залежать від багатьох параметрів: вихідного складу суспензії, дисперсності та фізико-хімічних властивостей порошку, функціонального матеріалу, реології суспензії, параметрів лиття, режимів термічної обробки тощо. Проте у літературі наявні дані лише щодо декількох із них. Зокрема, у роботах $[3,4]$ досліджували вплив диспергування порошку $\mathrm{BaTiO}_{3}$ на кінцеві характеристики діелектричних шарів та конденсатора, виготовленого на їх основі. Було показано, що попереднє диспергування порошку титанату барію в органічних розчинниках з низькою в'язкістю (етанол, толуол, суміш етанол/толуол) перед приготуванням суспензії [3] або додавання дисперсанту до складу суспензії [4] дозволяє зменшити шорсткість поверхні, пористість та збільшити густину плівки. При цьому відбувається значне покращення характеристик конденсатора: збільшення напруги пробою, ємності, зменшення внутрішнього опору. У свою чергу, у роботах $[5,6]$ досліджувався вплив дисперсності та вмісту порошку $\mathrm{BaTiO}_{3}$ на діелектричні властивості плівок. Було визначено, що збільшення концентрації порошку 3 10 до 40 об. \% призводить до збільшення діелектричної ємності сирої плівки. При цьому збільшення розміру частинок порошку з 0,1 до 1 мкм також призводить до зростання діелектричної ємності шару, щоправда в інтервалі концентрації порошку у плівці $10-40$ об. \% це збільшення лежить у межах 5 одиниць і набуває значної різниці за вмісту 
порошку 40 - 50 об. \% [5]. Подальший вплив концентрації порошку у плівці на значення діелектричної сталої залежить від дисперсності порошку. Так для порошків із дисперсністю 0,1 мкм збільшення концентрації понад 50 об. \% викликало зменшення діелектричної сталої. Подібний ефект спостерігався для порошків із розміром частинок 0,2 - 0,25 мкм за концентрації понад 55 об. \%, а з розміром 0,83 - 1 мкм - понад 60 об. \%. Автори [5] пов'язували такий вплив концентрації на значення діелектричної сталої зі збільшенням пустот та пор у плівці, що викликано надлишком твердої фази. Таке припущення цілком узгоджується з результатами роботи [6], де появу внутрішніх пор у плівці спостерігали за концентрації твердої фази понад 20 об. \%, а за концентрації 40 об. \% з'являлися міжфазні пори.

Отже, вплив багатьох вище перелічених параметрів залишається невизначеним. Скоріш за все це пов'язано із промисловим аспектом, коли налагоджене плівкове лиття стандартних суспензій забезпечує формування плівок із конкретними властивостями. Проте у контексті стоншення та підвищення якості поверхні за рахунок використання нанопорошків і вдосконалення складу суспензій та підбору оптимальних режимів здійснення лиття, питання впливу використання наночастинок $\mathrm{BaTiO}_{3}$ як на реологію, так і на властивості плівок, залишається відкритим. Також досить обмеженою є інформація щодо їх товщини, суцільності, шорсткості поверхні, особливостей їх термічної обробки та збірки у багатошарові нанокомпозити, їх взаємозв'язку з реологію суспензій. Тому одержання плівок на основі нанорозмірного порошку $\mathrm{BaTiO}_{3}$ i дослідження їх властивостей є надзвичайно актуальною невирішеною задачею.

Однією з найважливіших характеристик готової суспензії для плівкового лиття є їі реологія, а саме характер кривої течії. Переважна більшість суспензій для плівкового лиття мають псевдопластичний характер течії. Псевдопластичність у плівковому литті виявляє позитивний ефект через те, що зсувні напруження під час проходження суспензії під лезом філь'єри спричинюють зниження в'язкості, що дозволяє отримати меншу товщину плівки і ї̈ зростання після виходу з філь'єри, що запобігає розтіканню. Такий ефект дозволяє збільшити корисну ширину плівки, адже краї плівки не матимуть сильного скосу, що трапляється при литті суспензій з ньютонівським характером течії. Не менш важлива для плівкового лиття реологічна характеристика - тиксотропія, що надає суспензії здатності до відновлення початкової в'язкості та вихідної мікроструктури за припинення механічної дії на неї. Тому наявність тиксотропії в системі підвищує ії стабільність при зберіганні через сповільнення седиментації частинок порошку [2].

Оскільки під час процесу лиття на суспензію діють напруження зсуву, важливого значення набуває дослідження реологічних властивостей суспензій та їх залежність від 
вихідного складу. Виходячи із цього, метою даної роботи $є$ аналіз впливу окремих компонентів суспензій на основі нанопорошку $\mathrm{BaTiO}_{3}$ на їх реологічні властивості та властивості плівок, отриманих методом плівкового лиття.

\section{Об'скти та методика експерименту}

Приготування суспензій проводилось у два етапи. На першому етапі здійснювалась дезагрегація частинок порошку шляхом мокрого розмолу протягом 60 хвилин у планетарному мономлині Pulverisette 6 фірми Fritsch за швидкості обертання барабану 450 об/хв. Органічне в'яжуче готувалося шляхом розчинення полімеру полівінілбутиралю (ПВБ) 3 молекулярною масою 40000-75000 г/моль у чотирьох видах органічних розчинників: азеотропних сумішах ментон/етанол 40:60, метилетилкетон (MEК)/етанол 66:34 та чистих розчинниках етанолі та бутанолі з використанням магнітної мішалки RCT basic фірми IKA за швидкості обертання 1000 об./хв. У якості пластифікатору використовували дибутилфталат (ДБФ).

На другому етапі до суспензії наночастинок $\mathrm{BaTiO}_{3}(20-25$ нм, рис. 2) виробництва компанії «Нанотехцентр» (uа) додавали необхідну кількість органічного в’яжучого та продовжували гомогенізацію суспензії протягом 60 хв. у планетарному мономлині за швидкості обертання барабану 450 об./хв.

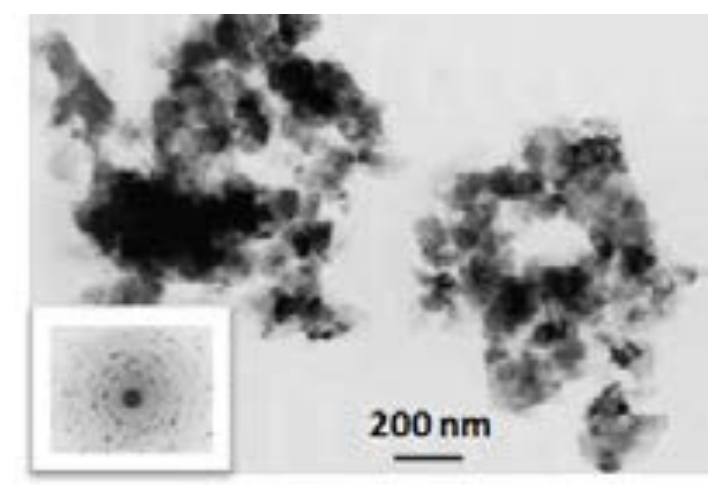

Рис. 2. Наночастинки $\mathrm{BaTiO}_{3}$

Реологічні властивості суспензій порошків $\mathrm{BaTiO}_{3}$ визначали за допомогою ротаційного віскозиметру Rheotest RN4.1 фірми Medingen в діапазоні напружень зсуву 1 1000 Па із зазором між коаксіальними циліндрами 1 мм та температурі $25^{\circ} \mathrm{C}$.

Плівки із суспензій $\mathrm{BaTiO}_{3}$ формували на машині ТТС-1200 3 максимальною швидкістю руху носія 55 см/хв. В якості носія використовували поліетилентерефталатну плівку з силіконовим антиадгезійним покриттям (Mylar). 
2D i 3D профілі поверхні, товщина, кількісні та якісні характеристики поверхні сирих плівок визначались за допомогою безконтактного інтерференційного 3D профілографу «Мікрон-альфа» фірми «Мікрон-система».

\section{Результати та обговорення}

Було отримано 9 суспензій різного складу. Вміст порошку складав від 20 до 40 мас. \%, полімеру від 2 до 7,6 мас. \%, пластифікатору від 3 до 8 мас. \%. Концентрація розчинника змінювалась від 20 до 61 мас. \% (табл. 1). Згідно 3 проведеними дослідженнями реологічних властивостей, усі одержані суспензії представляли собою структуровані неньютонівські системи зі складним характером течії. На відміну від традиційних псевдопластичних тиксотропних суспензій для плівкового лиття на основі мікронних та субмікронних порошків, досліджувані системи проявляли різний характер течії від майже ньютонівського до псевдопластичного реопексного в залежності від їх складу. Спільною тенденцією було збільшення ефективної в'язкості за низьких напружень зсуву (до 20 Па), подальша ділянка ньютонівської течії і наступне зниження ефективної в’язкості за рахунок прояву в’язкопружних властивостей (табл. 2).

Таблиця 1.

Склад досліджуваних суспензій

\begin{tabular}{|c|c|c|c|c|c|c|c|}
\hline \multirow{2}{*}{ Суспензія } & \multirow{2}{*}{$\begin{array}{c}\text { Вміст } \\
\text { порошку } \\
\mathrm{BaTiO}_{3}, \\
\text { мас. \% } \\
\end{array}$} & \multicolumn{4}{|c|}{ Вміст розчиннику, мас. \% } & \multirow{2}{*}{$\begin{array}{c}\text { Вміст органічної } \\
\text { зв’язки, мас. \% }\end{array}$} & \multirow{2}{*}{$\begin{array}{c}\text { Вміст } \\
\text { пласти- } \\
\text { фікатору } \\
\text { ДБФ, мас. \% }\end{array}$} \\
\hline & & Етанол & Бутанол & Ментон & $\begin{array}{c}\text { Метил- } \\
\text { етилкетон }\end{array}$ & & \\
\hline TCS-14 & 29,50 & 36,81 & - & 24,54 & - & 3,93 & 4,33 \\
\hline TCS-15 p1 & 29,50 & - & 61,36 & - & - & 3,93 & 4,33 \\
\hline TCS-15 p2 & 28,28 & - & 60,89 & - & - & 3,77 & 6,22 \\
\hline TCS-15 p3 & 27,15 & - & 60,45 & - & - & 3,62 & 7,96 \\
\hline TCS-16 & 29,50 & 20,86 & - & - & 40,50 & 3,93 & 4,33 \\
\hline TCS-17 & 19,42 & 41,48 & - & 27,65 & - & 5,18 & 5,70 \\
\hline TCS-18 & 39,84 & 32,03 & - & 21,35 & - & 2,66 & 2,92 \\
\hline TCS-19 & 28,38 & 35,42 & - & 23,61 & - & 7,57 & 4,16 \\
\hline TCS-20 & 30,09 & 37,55 & - & 25,04 & - & 2,01 & 4,41 \\
\hline TCS-21 & 35,67 & 33,96 & - & 22,64 & - & 3,17 & 3,49 \\
\hline TCS-22 & 32,92 & 35,23 & - & 23,49 & - & 3,51 & 3,86 \\
\hline
\end{tabular}

\section{Вплив розчиннику}

3 наведених профілів в’язкості (рис. 3) видно, що ефективна в’язкість системи визначається типом розчинника. 3 літературних джерел відомо [7, 8], що за своєю природою полімерні ланцюжки мають певну гнучкість, завдяки якій макромолекули зігнуті, і тому полімер має розпушену структуру 3 великими міжмолекулярними порожнинами. Перша стадія взаємодії твердофазного полімеру з розчинником - набухання полімеру. Коли набухання досягає точки розплутування, фронт розчинення просувається 
всередину твердого полімеру $[9,10]$. При цьому взаємодія полімеру та розчинника супроводжується процесами сольватації та асоціації (структуроутворенням) [11, 12], які призводять до формування структурної сітки з молекулярних зчеплень та переплутувань «флуктуаційної» сітки, в якій міжмолекулярні зв'язки безперервно утворюються та руйнуються [13]. Проте, формування флуктуаційної сітки полімеру можливе лише за необмеженого набухання полімеру у розчиннику i за умови їх термодинамічної спорідненості.

Таблиця 2.

Реологічні властивості суспензій

\begin{tabular}{|l|c|c|c|c|c|}
\hline Суспензія & $\begin{array}{c}\text { Ефективна } \\
\text { в'язкість } \eta_{180}, \text { Па·с }\end{array}$ & $\begin{array}{c}\text { Ефективна } \\
\text { в'язкість } \eta_{100}, \text { Па·с }\end{array}$ & $\begin{array}{c}\text { Ефективна } \\
\text { в'язкість } \eta_{50}, \text { Па·с }\end{array}$ & $\begin{array}{c}\text { Ефективна } \\
\text { в'язкість } \eta_{30}, \text { Па·с }\end{array}$ & $\begin{array}{c}\text { Максимальне } \\
\text { напруження зсуву, } \\
\text { Па }\end{array}$ \\
\hline TCS-16 & 47 & 42 & 37 & 20 & 54 \\
\hline TCS-20 & 63 & 61 & 59 & 57 & 59 \\
\hline TCS-15 & 180 & 182 & 184 & 178 & 79 \\
\hline TCS-17 & 280 & 282 & 286 & 283 & 85 \\
\hline TCS-22 & 290 & 290 & 295 & 300 & 86 \\
\hline TCS-14 & 325 & 337 & 356 & 361 & 89 \\
\hline TCS-21 & 450 & 500 & 550 & 550 & 92 \\
\hline TCS-18 & - & 700 & 850 & 955 & 97 \\
\hline TCS-19 & - & - & - & 3600 & \\
\hline
\end{tabular}

Для встановлення впливу типу розчинника на реологічні властивості суспензії та якість отриманих із них плівок було порівняно три системи з різними розчинниками.

Таблиця 3.

Вплив зміни типу розчинника на профіль поверхні та товщину плівок

\begin{tabular}{|c|c|c|c|c|}
\hline Назва системи & Розчинник & h, мкм & Ra, нм & Rz, $\mathrm{HM}$ \\
\hline TCS-14 & Menthone/Etanol - 40/60 & 3,5 & $57-86$ & $123-317$ \\
\hline TCS-15 & Butanol & 3 & $45-93$ & $128-210$ \\
\hline TCS-16 & MEK/Etanol - 66/34 & 2 & $37-63$ & $168-317$ \\
\hline
\end{tabular}

Система TCS-14 на основі розчинника Ментон-Етанол виявляє найбільший приріст ефективної в’язкості в області низьких напружень зсуву. В порівнянні з іншими системами, TCS-14 має найбільш виражену тиксотропію, що свідчить про високу структурованість системи. Поведінку системи можна пояснити обмеженим набуханням полімеру в суміші розчинників та не повною взаємодією з частинками твердої фази, спричинену ускладненням потрапляння частинок до не повністю розрівняних ділянок полімерного ланцюга. Такий висновок підтверджується широким розкидом значень критерію шорсткості Rz (табл. 3) через вихід подібних структурних одиниць на поверхню 
сирої плівки. Більшу товщину плівки, отриманої із суспензії TCS-14, можна пояснити значною в'язкістю системи.

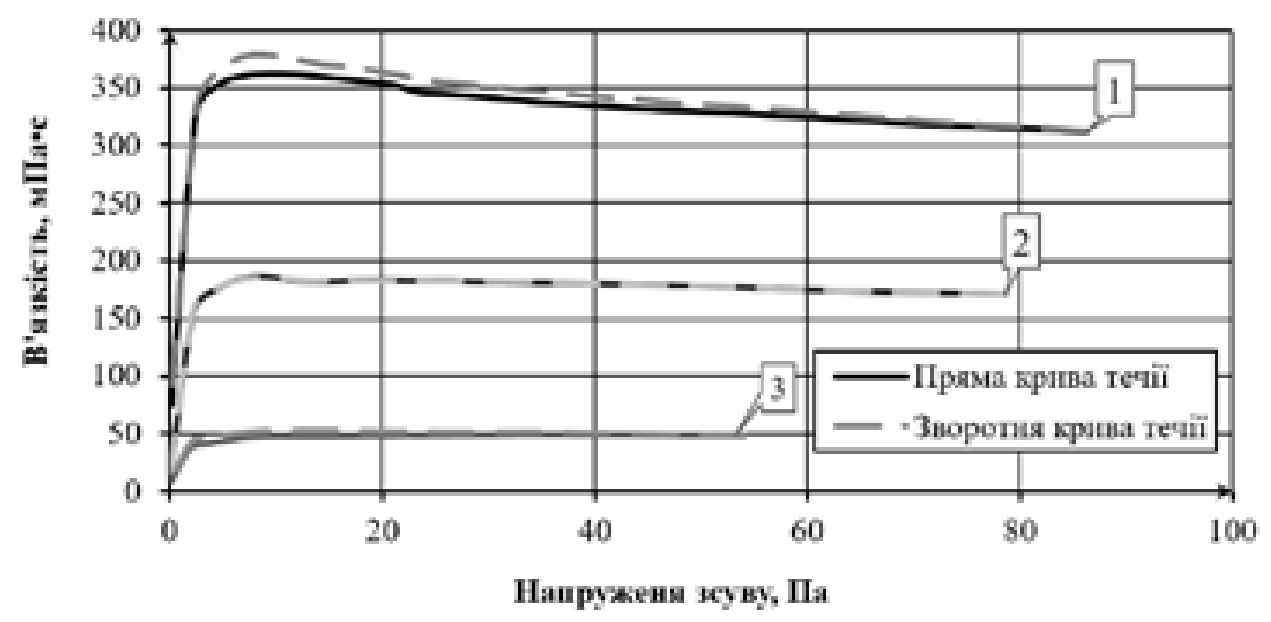

Рис. 3. Залежність в'язкості від напруження зсуву для суспензіїй на основі різних розчинників: 1 - TCS-14 (Menthone/Etanol); 2 - TCS-15 (Butanol); 3 - TCS-16 (MEK/Etanol).

Нижча в’язкість систем TCS-15 та 16 досягається за рахунок кращого розчинення полімеру та кращого диспергування частинок в суспензії. Однак, у системах із низькою в’язкістю спостерігається зменшення граничної межі зсуву, що вказує на меншу здатність системи до зсувного деформування і загалом про меншу міцність вихідної мікроструктури системи. Виходячи з отриманих даних, зростання ефективної в'язкості системи спричиняє збільшення товщини плівки. Отримані дані корелюють із дослідженнями авторів роботи [14], що розглядали три подвійні системи розчинників і стверджують, що для отримання тонких плівок найкраще підходять низьков'язкі системи з псевдопластичним характером течії.

\section{Вплив полімеру}

Для покращення якості плівок було приготовано і порівняно три експериментальні суміші розчинів полімерів (табл. 4). Криві течії отриманих сумішей подані на рис. 4.

Таблиця 4 .

Склад досліджуваних сумішей полімерів

\begin{tabular}{|c|c|c|}
\hline Назва & Склад & Розчинник \\
\hline Y-1 & $\begin{array}{l}50 \% 75000 \text { ПВБ + } \\
50 \% 40000 \text { Бутвар }\end{array}$ & азеотропна суміш етил ацетат - етиловий спирт \\
\hline Y-2 & $\begin{array}{l}75 \% 75000 \text { ПВБ + } \\
25 \% 40000 \text { Бутвар }\end{array}$ & азеотропна суміш етил ацетат - етиловий спирт \\
\hline Y-3 & $\begin{array}{l}25 \% 75000 \text { ПВБ + } \\
75 \% 40000 \text { Бутвар }\end{array}$ & азеотропна суміш етил ацетат - етиловий спирт \\
\hline
\end{tabular}




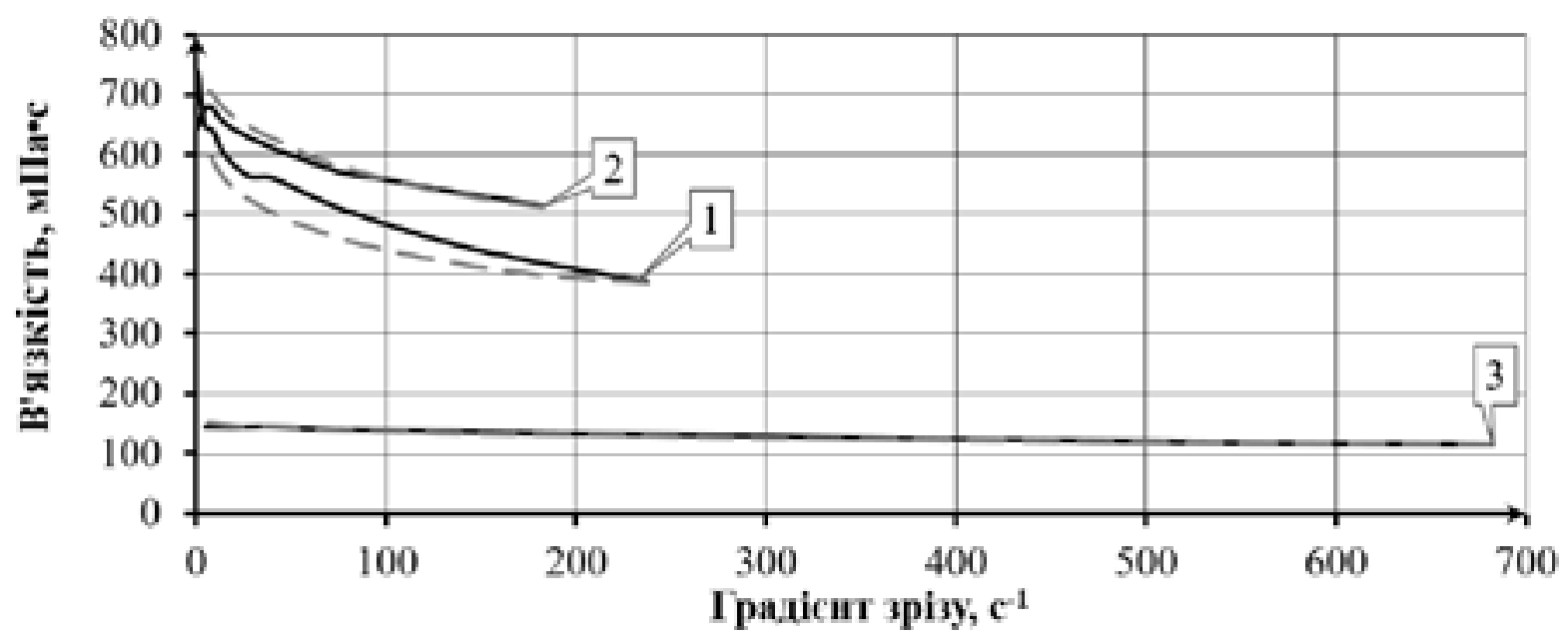

Рис. 4. Залежність в'язкості від градієнту зрізу для різних сумішей полімерів: 1 - Y$1,2-\mathrm{Y}-2,3-\mathrm{Y}-3$

Обрана для подальшої роботи суміш полімерів Y-3 мала найнижчу в’язкість, найбільше максимальне напруження зсуву та псевдопластичний характер течії 3 незначною тиксотропією на початку кривої течії. Такий тип течії вважається найбільш придатним для отримання тонких плівок методом плівкового лиття $[2,14]$. Також у суміші Y-3 була відсутня ділянка збільшення ефективної в’язкості за низьких напружень зсуву, що характерна для розчинів чистих полімерів при тих же концентраціях (рис. 5).

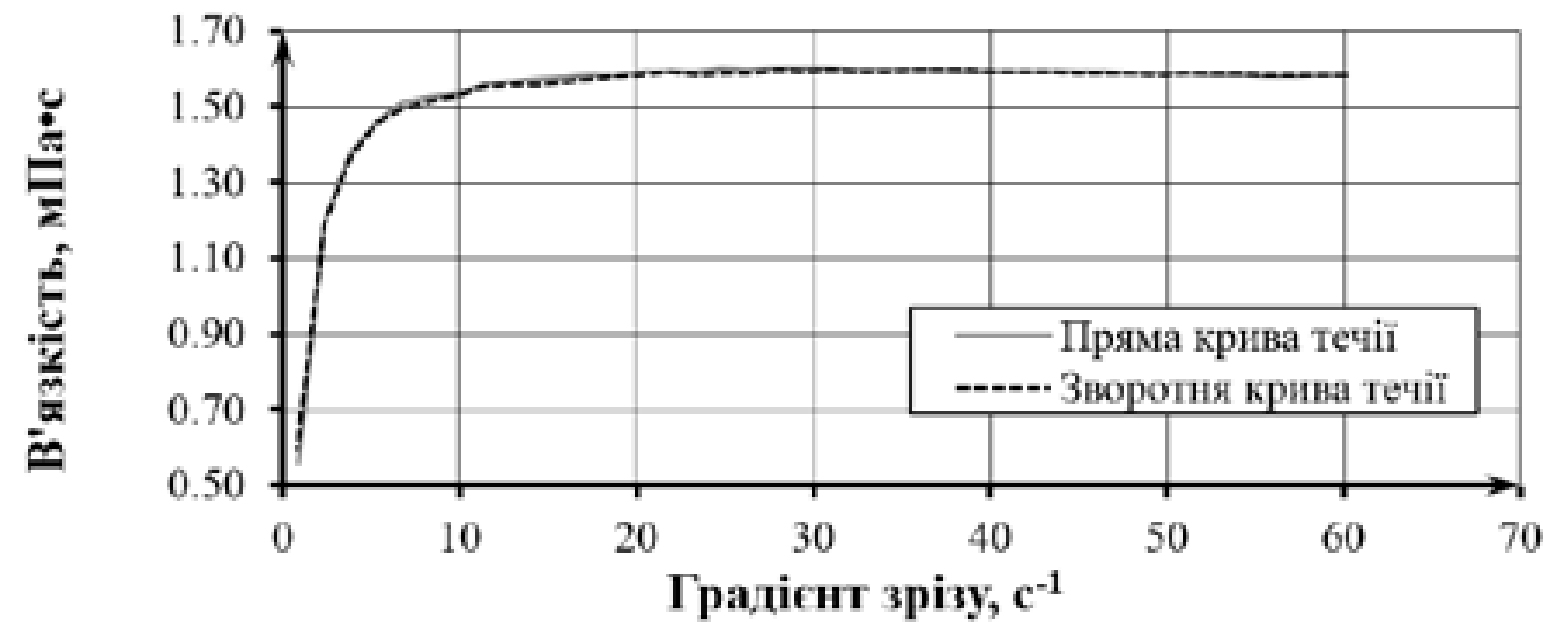

Рис. 5. Крива течії 10\% розчину ПВБ (75 000 г/моль) в етиловому спирті

Кількість полімеру повинна бути достатньою для формування полімерної матриці, в якій будуть знаходитися частинки порошку. Збільшення кількості полімеру в суспензії призводить до зростання в'язкості, як і використання полімерів із високою молекулярною 
масою. 3 наведених реологічних кривих видно, що вирішальний вплив на в'язкість суспензії здійснює концентрація полімеру у розчині. Значне збільшення в'язкості в суспензії 3 високо концентрованим розчином полімеру спричинене формуванням флуктуаційної структурної сітки, сформованої з полімерних ланцюгів, великою кількістю їх випадкових переплетень та зачеплень. Про наявність складної структури говорить значна тиксотропія, що виражена в широкій петлі гістерезису між прямою та зворотньою кривою течії (рис. 6, в). Цікавим фактом $є$ прояв тиксотропії у суспензії з сумішшю полімера низької концентрації (рис. 6, а). Суспензія TCS-14 займає середнє значення між двома крайніми випадками, виявляючи незначну структурованість при максимальному напруженні зсуву, близькому до TCS-19, що говорить про високу межу міцності системи.(рис. 6, б).
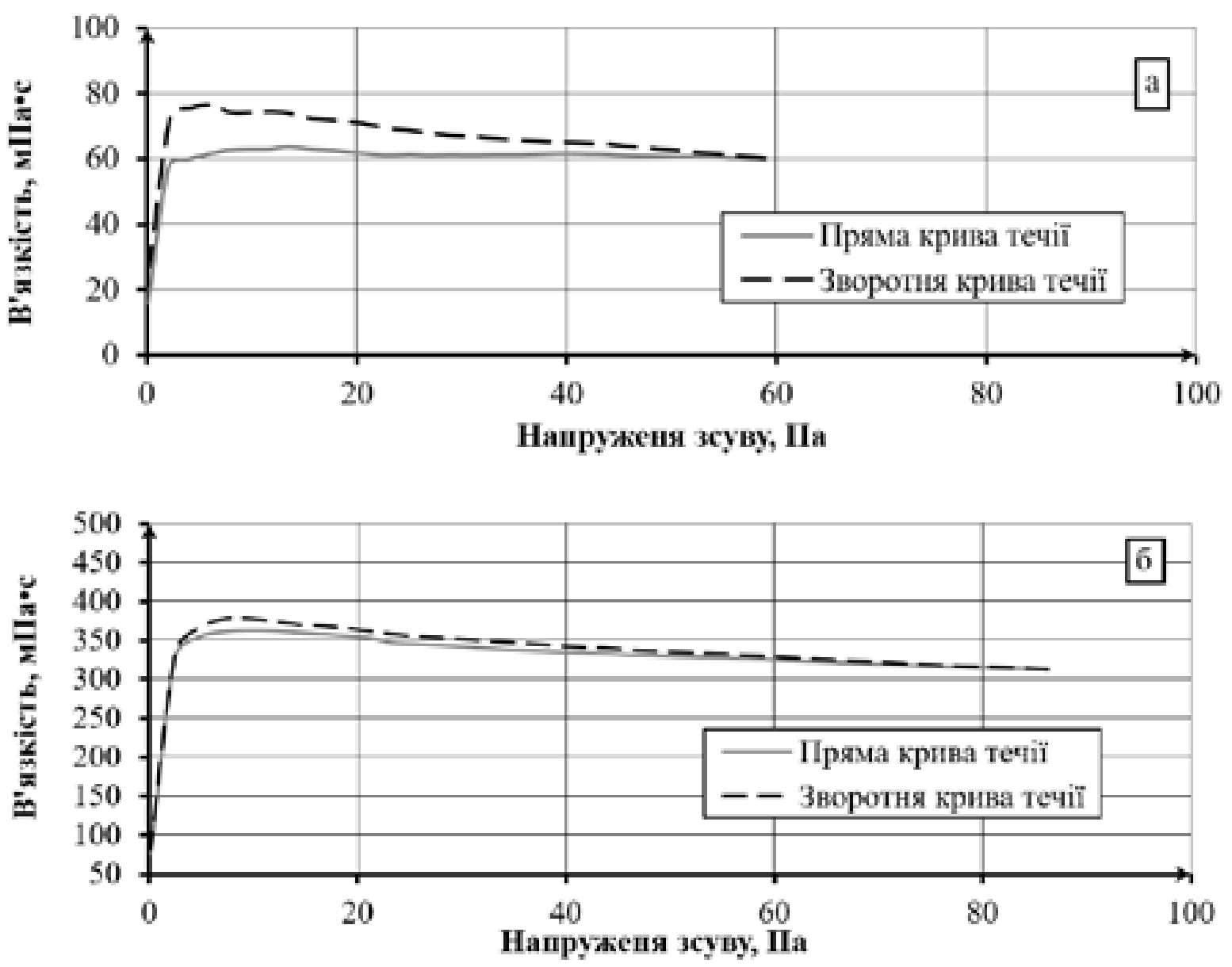


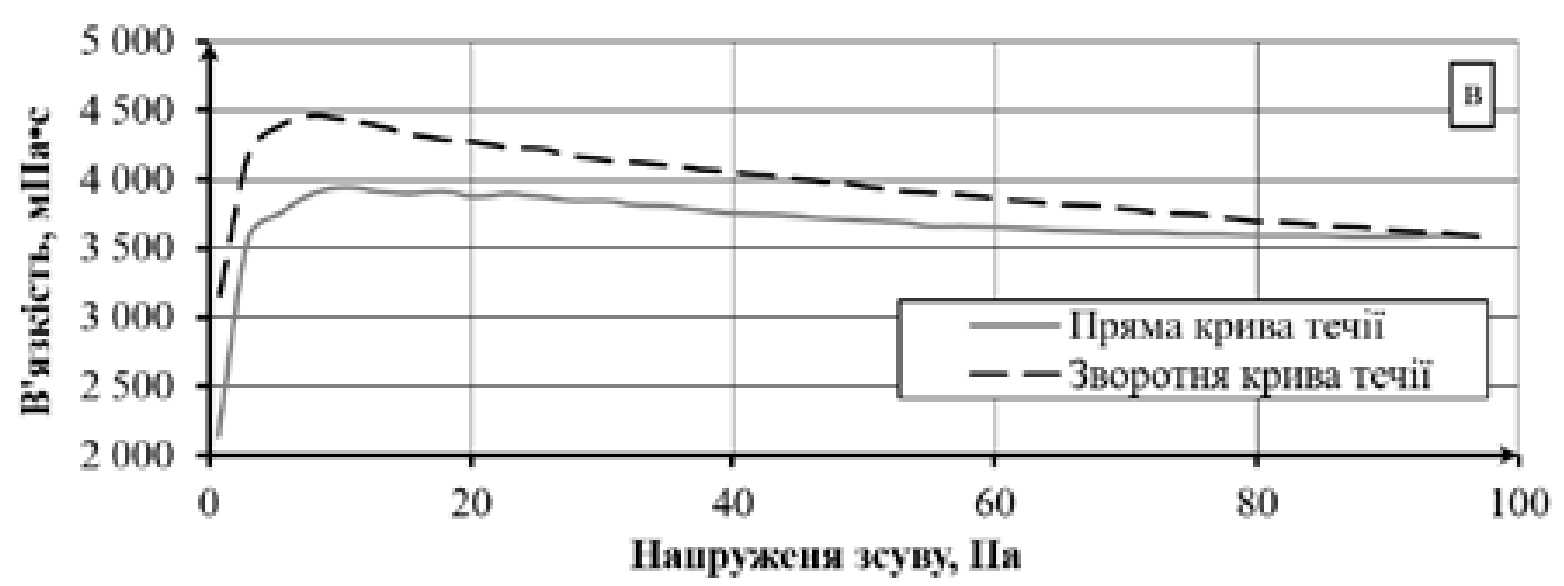

Рис. 6. Залежність в'язкості від напруження зсуву для суспензії з різною концентрацією органічної зв’язки: а - TCS-20 (2 мас. \%); б - TCS-14 (3,9 мас. \%); в TCS-19 (7,6 мас. \%).

Автори роботи [15], що використовували два полімери ПВБ В-98 (низька молекулярна маса) та В-76 (висока молекулярна маса), встановили, що застосування зв'язки з більш високою молекулярною масою призводило до збільшення в'язкості вдвічі (200 та 400 мПа с відповідно). Збільшення кількості розчинника по відношенню до кількості зв'язки зменшувало в'язкість. Також автори зазначають, що збільшення масового вмісту зв'язки в системі з 8 до $10 \%$ мас. навпаки призводило до зменшення в'язкості.

Слід пам'ятати, що полімер виконує допоміжну функцію у формуванні тонких керамічних плівок і видаляється на стадії відгонки, що передує спіканню. Високий вміст полімеру в суспензії може призвести до збільшення пористості, якщо втрата об’єму, який він займав, не буде компенсована ростом зерен твердої фази.

Таблиця 5.

Залежність товщини плівки від концентрації органічної зв’язки в суспензії

\begin{tabular}{|c|c|c|c|}
\hline Назва системи & Концентрація органічної зв'язки, \% мас. & h, мкм & Ra, нм \\
\hline TCS-19 & 7,6 & 5 & 45 \\
\hline TCS-14 & 3,9 & 3 & 49 \\
\hline TCS-20 & 2 & 1,5 & 38 \\
\hline
\end{tabular}

Підтверджується залежність товщини плівки від в’язкості суспензії. Збільшення шорсткості плівки при високій концентрації полімеру пояснюється виходом на поверхню плівки клубків зчеплених полімерних ланцюгів. 


\section{Вплив порошку}

Введення великої кількості порошку в систему значно підвищує в'язкість та сильно змінює характер течії суспензії. Поступове збільшення вмісту твердої фази очікувано призводить до збільшення в'язкості та посилення тиксотропного характеру течії суспензії (рис. 7). Збільшення концентрації твердої фази більше 30 мас. \% призводить до екстремального збільшення тиксотропії. Суспензії TCS-21 та 18 проявляють дилатантний характер течії на початку кривої течії, відстань між частинками порошку збільшується, в утворені вільні області потрапляє більша кількість твердої фази. Подальше збільшення зсувних напружень руйнує структуру, залишаючи в об'ємі суспензії вільні частинки порошку і частинки 3 приєднаними ланцюгами полімерів. Поступове зниження зсувних напружень спричиняє тертя між утвореними структурними одиницями, витісняючи рідину 3 міжконтактної зони, що в свою чергу призводить до збільшення тертя через відсутність рідкої фази, що виконує функцію лубриканту. Розвинена поверхня частинок посилює це явище. Такою поведінкою системи можна пояснити високі значення в'язкості при низьких напруженнях зсуву на зворотній кривій течії (рис. 8). Також закономірним є збільшення товщини отриманих плівок (табл. 6).

Таблиця 6.

Залежність товщини плівки від кількості порошку в суспензії

\begin{tabular}{|c|c|c|c|}
\hline Назва системи & Кількість порошку, \% мас. & $\mathrm{h}$, мкм & $\mathrm{Ra}$, нм \\
\hline TCS-17 & 19 & 2 & 52 \\
\hline TCS-14 & 30 & 3 & 49 \\
\hline TCS-18 & 40 & 3,5 & 40 \\
\hline
\end{tabular}

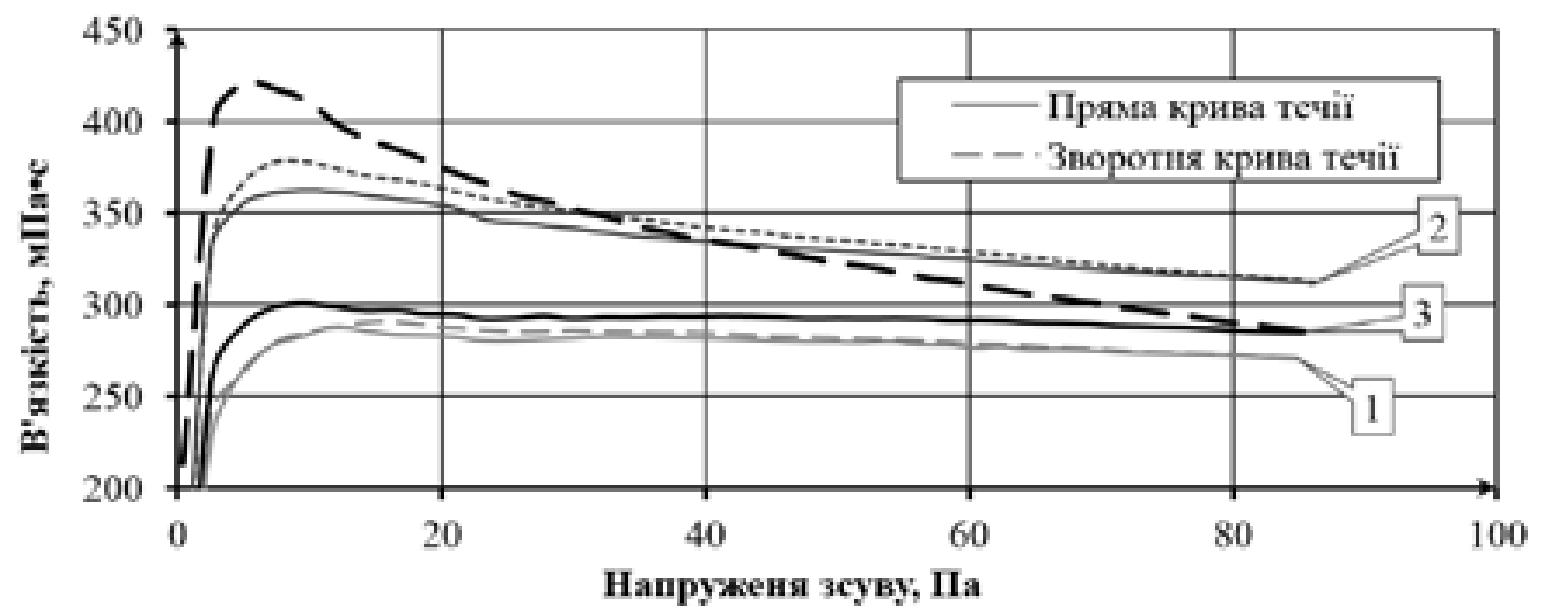

Рис. 7. Залежність в'язкості від напруження зсуву для суспензій з різним вмістом порошку: 1 - TCS-17 (19\% мас. порошку); 2 - TCS-14 (30\% мас. порошку); 3 - TCS-22 (33\% мас. порошку). 


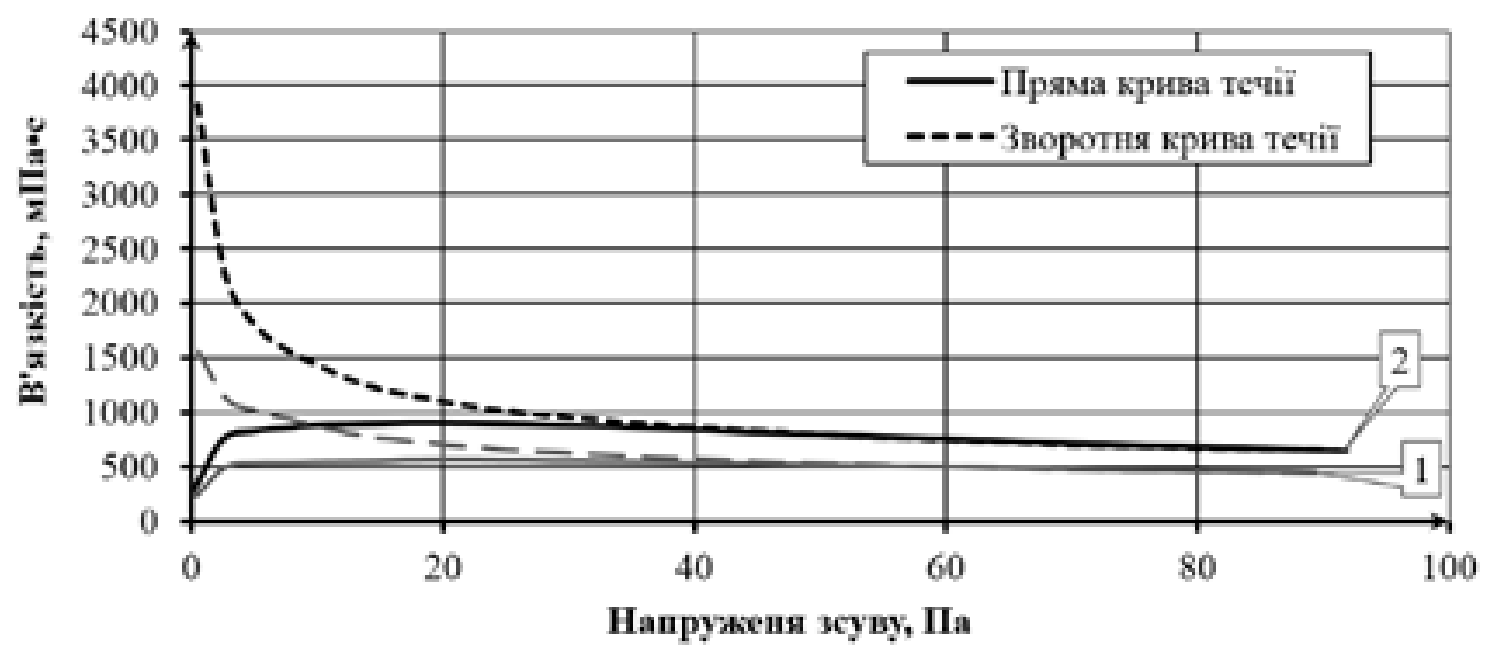

Рис. 8. Залежність в'язкості від напруження зсуву для суспензій з різним вмістом порошку: 1 - TCS-21 (36\% мас.); 2 - TCS-18 (40\% мас.).

Спостерігається збільшення максимального значення напруження зсуву при збільшенні вмісту порошку в системі (табл. 7).

Таблиця 7.

Вплив вмісту порошку в системі на максимальне напруження зсуву

\begin{tabular}{|c|c|c|}
\hline Назва системи & Вміст порошку, \% мас. & Максимальне напруження зсуву, Па \\
\hline TCS-17 & 15 & 84.75 \\
\hline TCS-14 & 25 & 86.30 \\
\hline TCS-18 & 40 & 91.79 \\
\hline
\end{tabular}

Автори роботи [16], що досліджували вплив концентрації твердої фази на реологічні властивості суспензії, зазначають, що при малій кількості твердої фази суспензії мали майже ньютонівський характер течії, з ледь вираженою псевдопластикою. Однак, при високому вмісті твердої фази в'язкість зростає сильніше і суспензія стає більш псевдопластичною. В роботі [15] стверджується, що використання менших порошків із більшою питомою площею поверхні підвищує в’язкість

\section{Вплив пластифікатору}

Введення пластифікатору необхідне для отримання гнучких та пластичних плівок, що потрібно для відділення плівки від носія без руйнування та подальших механічних дій над ними на кшталт скручування чи складання. Існує два основних механізми пластифікації Внутрішньоструктурна пластифікація відбувається, коли термодинамічна спорідненість пластифікатору до полімеру є високою, він послаблює сили взаємодії макромолекул полімеру між собою, утворюючи істинний розчин. Міжструктурна 
пластифікація відбувається на структурному рівні, коли структурний пластифікатор обмежено суміщається 3 полімером і розподіляється між його надмолекулярними структурними елементами. Пластифікатор діє як лубрикант, зменшуючи тертя між агрегатами молекул полімеру. Дибутилфталат, що застосовувався у досліджених суспензіях, відноситься до пластифікаторів із низькою молекулярною масою (273 г/моль), що покращує його проникнення в полімерну сітку. Очікувано, що збільшення концентрації пластифікатору в системі призводить до зменшення іiї в'язкості (рис. 9). Окрім того, певний вклад в пониження в'язкості створює розбавлення системи при додаванні розчину пластифікатора в більших кількостях.

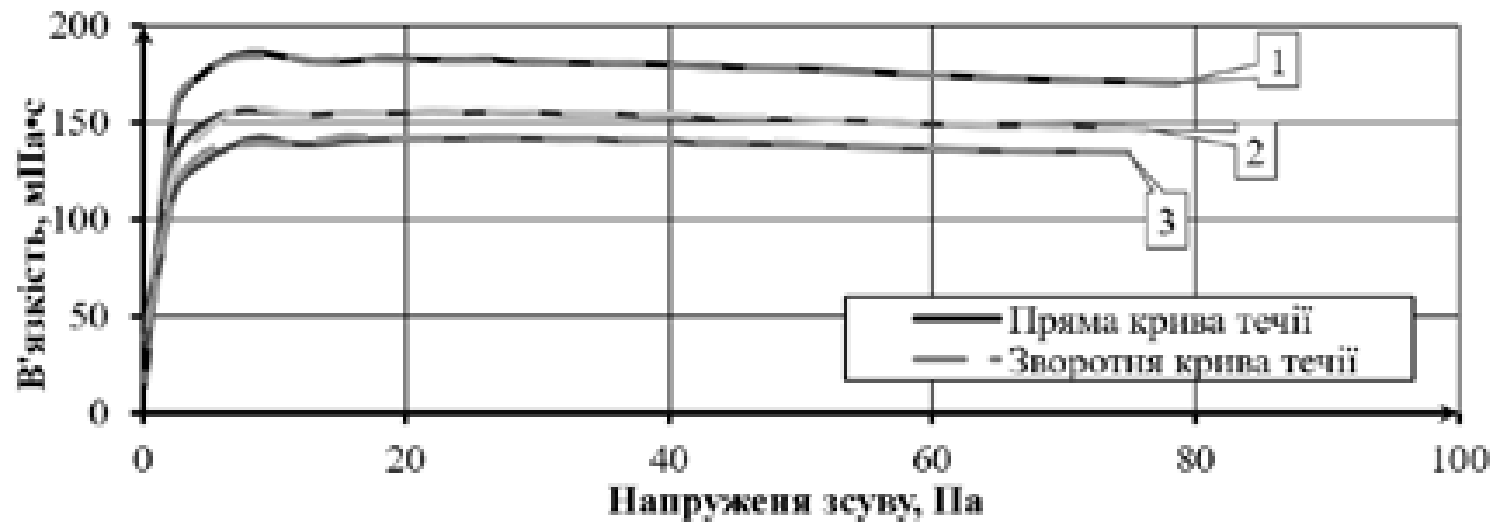

Рис. 9. Залежність в'язкості від напруження зсуву для суспензії TCS-15 (на основі бутанолу) з різним вмістом пластифікатору: 1 - 4,3\% мас.; 2 - 6,3\% мас.; 3 - 8\% мас.

Автори роботи [17], що досліджували вплив поліетиленгліколю 3 різною молекулярною масою, застосованого в якості пластифікатору на в’язкість системи, встановили ефект зниження в'язкості при зниженні молекулярної маси ПЕГ. Автори припускають, що зменшення молекулярної маси полегшує проникнення ланцюгів ПЕГ до частинок $\mathrm{BaTiO}_{3}$ та ланцюгів ПВБ. Молекулярна маса пластифікатору є домінуючим фактором у контролі в'язкості суспензії.

Оптимальний вміст пластифікатора визначається необхідними механічними властивостями сирої плівки. 


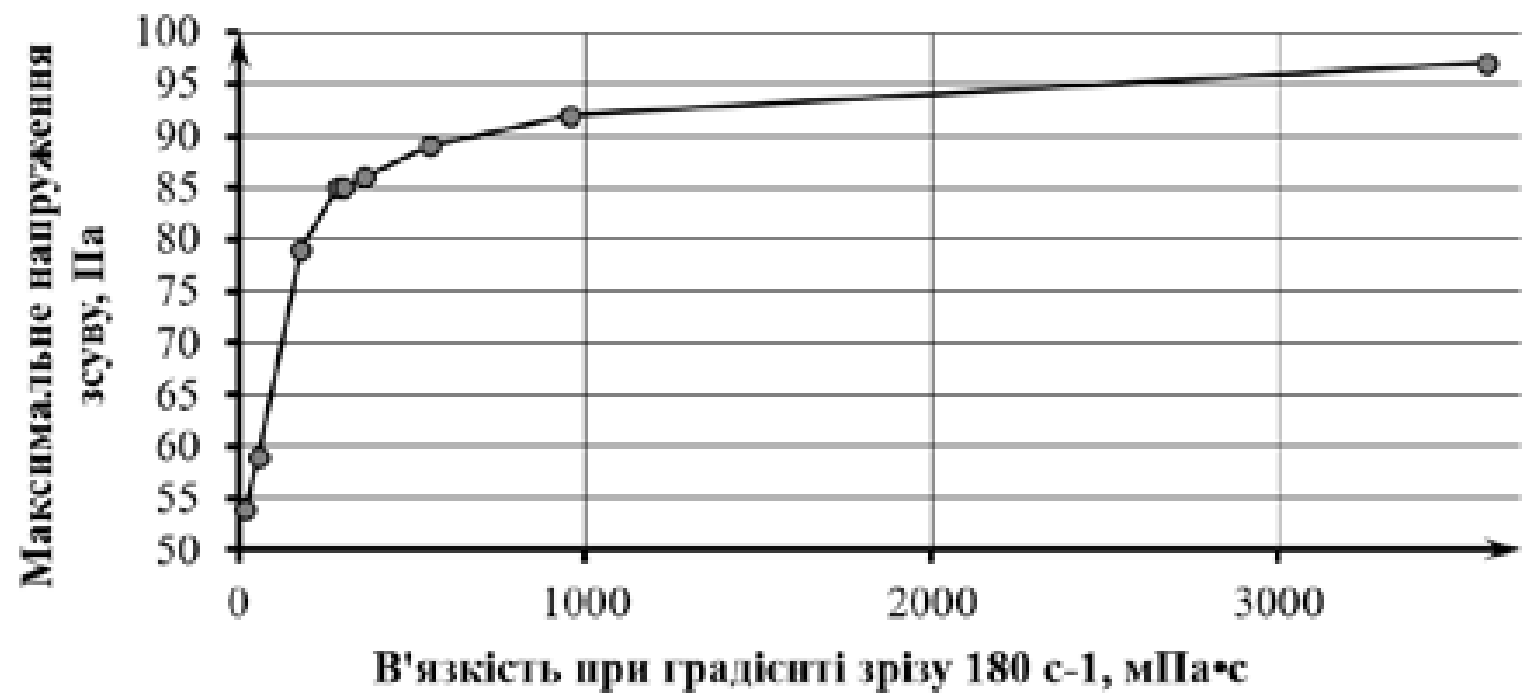

Рис. 10. Залежність максимального напруження зсуву від в'язкіості суспензії при градієнті зрізу $30 \mathrm{c}^{-1}$

3 рис. 10 видно, що максимальне напруження зсуву зростає по мірі збільшення в’язкості суспензій, ця тенденція є спільною для всіх досліджуваних суспензій.

\section{Висновки}

Всі компоненти суспензії в більшій чи меншій мірі чинять вплив на реологічні властивості суспензії, що в подальшому впливає на властивості плівок, отриманих із цих суспензій. Регулюючи тип та кількість кожного компоненту, можливо отримати суспензії 3 різною в'язкістю, плівки 3 різною товщиною, шорсткістю, щільністю та гнучкістю. Проведені дослідження показують, що найкращу здатність до формування тонких плівок iз низькою шорсткістю виявляють суспензії 3 псевдопластичним тиксотропним характером кривої течії що вказує на розвинену структуру, що створена полімерною матрицею та частинками твердої фази. Оптимальна концентрація полімеру лежить в межах 2-4 мас. \%, співвідношення полімер - пластифікатор: 1:1, вміст твердої фази не більше 30 мас. \%. Отримані з таких суспензій плівки мали найнижчу шорсткість, товщину та були достатньо міцними для відділення від носія.

\section{Перелік посилань}

1. Greater capacity for batteries makes smaller devices (2014, September 11). Режим доступу: http://phys.org/news/2014-09-greater-capacity-batteries-smaller-devices.html (дата звернення: 23.09.16). 
2. Mistler, R.E., Twiname, E.R. Tape Casting: Theory and Practice / R.E. Mistler, E.R. Twiname // The American Ceramic Society - 735 Ceramic Place, Westerville, Ohio 43081. - 2000. - P. $79-82$.

3. Pat. 2012/0048452 B2 US, Int. CI. C04B 35/64 (2006.01), B32B 37/02 (2006.01), C04B 35/622 (2006.01). Method of manufacturing ceramic paste for multilayer ceramic electronic component and method of manufacturing multilayer ceramic electronic component having the same / J.M. Suh (KR), W.S. Choi (KR), J.H. Bae (KR), H. Kim (KR); assignee Samsung ElecroMechnics Co., LTD (KR). - Appl. No. 13/191,053; filed 26.07.2011; publicised 01.03.2012. - 6 p.

4. Pat. 2012/0147514 A1 US, Int. CI. H01G 4/30 (2006.01), B32B 37/06 (2006.01), B32B 37/14 (2006.01), C04B 35/00 (2006.01), B32B 37/02 (2006.01). Ceramic paste composition for multilayer ceramic capacitor, multilayer ceramic capacitor comprising the same and methods of manufacturing the same / J.M. Suh (KR), H. Kim (KR), H. Lee (KR); assignee Samsung ElecroMechnics Co., LTD (KR). - Appl. No. 13/116.526; filed 26.06.2011; publicised 14.06.2012. - 6 p.

5. Paik, K.-W. Epoxy/BaTiO3(SrTiO3) composite films and pastes for high dielectric constant and low tolerance embedded capacitors in organic substrates / K.-W. Paik, J.-G. Hyun, S. Lee, R.-W. Jang // Electronic Systemintegration Technology: Conf., 2006, Dresden, Germany. :proc. of conf.- September 5-7, 2006. - P. $794-801$.

6. Kuo, D.-H. Dielectric behaviors of multi-doped BaTiO3/epoxy composites / D.-H. Kuo, Ch.Ch. Chang, T.-Y. Su, W.-K. Wang, B.-Y. Lin // Journal of the European Ceramic Society. 2001. - Vol. 21, No. 9. - P. 1171 - 1177.

7. Штаркман Б.П. Пластификация поливинилхлорида / Б.П. Штаркман. - М.: Химия. 1975. $-248 \mathrm{c}$.

8. Лосев, И.П. Химия синтетических полимеров / И.П. Лосев, Е.Б. Тростянская.- М.: Книга по требованию. $-2012 .-610$ с.

9. Navard, P. Preparation and properties of cellulose solutions / P. Navard, F. Wendler, F. Meister, M. Bercea, T. Budtova // The European Polysaccharide network of excellence (EPNOE). - Springer Vienna, 2012. - P. 91 - 152.

10. Chaudemanche, C. Swelling and dissolution mechanisms of regenerated Lyocell cellulose fibers / C. Chaudemanche, P. Navard // Cellulose. - 2011. - Vol. 18, No. 1. - P. 1 - 15.

11. Тагер, А.А. Физико-химия полимеров, 2-е издание / А.А. Тагер. - М.: Химия, 1968. $536 \mathrm{c}$.

12. Тугов, И.И. Химия и физика полимеров / И.И. Тугов. - М.:Химия, 1989. -432 с. 
13. Азаров, В.И. Химия древесины и синтетических полимеров: Учебник для вузов / В.И. Азаров, А.В. Буров, А.В. Оболенская, - СПб.:СПбЛТА. - 1999. - 628 с. ISBN 5-230-105690.14. Vinothini, V., Singh, P., Balasubramanian, M. Optimization of barium titanate nanopowder slip for tape casting / V. Vinothini, P. Singh, M. Balasubramanian // Journal of Materials Science. - Vol. 41. - 2006. - P. 7082-7087.

15. Dae-Hwan Kim, Kyung-Yul Lim, Ungyu Paik, Yeon-Gil Jung. Effects of chemical structure and molecular weight of plasticizer on physical properties of green tape in BaTiO3/PVB system / K. Dae-Hwan, L. Kyung-Yul, P. Ungyu, J. Yeon-Gil // Journal of the European Ceramic Society - Vol. 24. - 2004. - P. 733-738.

16. Dang-Hyok Yoon, Burtrand I. Lee. Processing of barium titanate tapes with different binders for MLCC applications-Part I: Optimization using design of experiments / Y. Dang-Hyok, I.L Burtrand // Journal of the European Ceramic Society. - Vol. 24. - 2004. - P. 739-752.

17. Kyung Yul Lim, Dae Hwan Kim, Ungyu Paik, Seong Hun Kim. Effect of the molecular weight of poly(ethylene glycol) on the plasticization of green sheets composed of ultrafine BaTiO3 particles and poly(vinyl butyral) / Y.L. Kyung, H.K. Dae, P. Ungyu, H.K. Seong // Materials Research Bulletin. - Vo. 38. - 2003. - P. 1021-1032. 